УДК [929+94+327] (477.6)

DOI: https://doi.org/10.33782/eminak2019.2(26).307

\title{
КОНСУЛЬСЬКА СЛУЖБА НІМЕЧЧИНИ У ПІВНІЧНОМУ ПРИАЗОВ'Ї ОЧИМА БЕРДЯНСЬКИХ ІСТОРИКІВ
}

\author{
[рец.]: Лиман I., Константінова В. Німецькі консули в Північному Приазов'ї. \\ Дніпро: ЛІРА, 2018500 с.
}

\section{Олександр Тригуб}

Чорноморський національний університет імені Петра Могили (Миколаїв, Україна) e-mail: alextrigub@ukr.net

ORCID: https://orcid.org/0000-0003-0610-1702

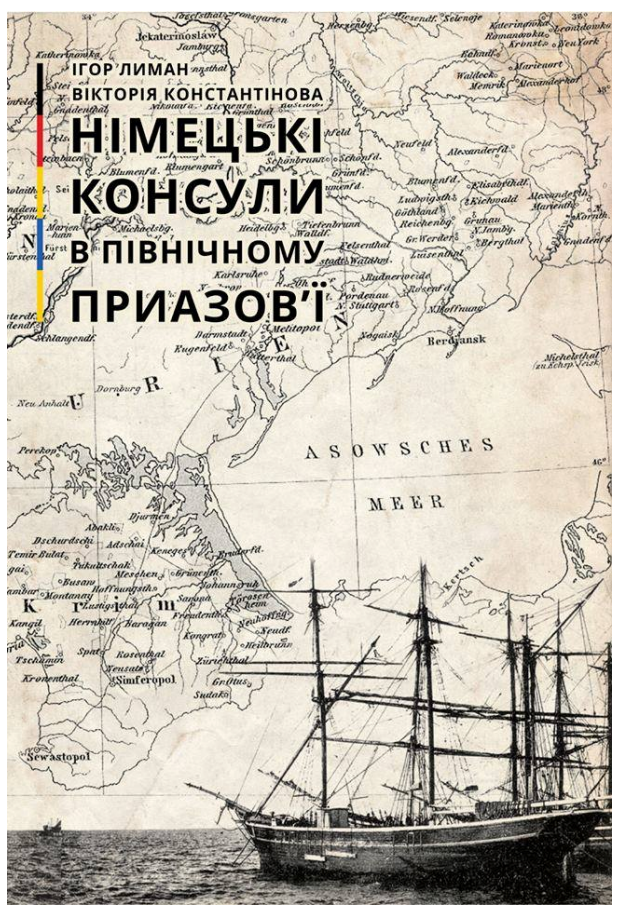

Все частіше вітчизняні науковці звертають свою увагу на досить незвичний для української історіографії (якщо враховувати рівень вивчення) аспект історії міжнародних відносин - історія іноземних консульств та їх представників на теренах українських земель. Лише у XXI ст. було дано початок (і це без перебільшення) подібного роду дослідженням. При цьому вже сьогодні ми можемо спостерігати формування декількох осередків даного дослідницького напрямку: Київ (I. Матяш, I. Жалоба), Львів (В.Ададуров, Б. Чума), Одеса (Л. Білоусова, О. Феденко), Миколаїв (Л. Вовчук, О. Тригуб), Бердянськ (І. Лиман, В. Константінова). I, як не дивно, саме бердянські вчені $\epsilon$ найбільш продуктивними у випуску монографічної продукції, що презентує життєві портрети консулів та аналіз їх діяльності в азовському регіоні.

У 2018 р. завдяки зусиллям Ігоря Лимана та Вікторії Константінової побачила світ чергова (четверта) книга із серії «ІІторія іноземних консульств на Півдні України», яка присвячена історії німецьких консульств, що діяли у Північному Приазов"ї в період від заснування у регіоні представництв Пруссії та великого герцогства Мекленбург-Шверін після Кримської війни і до закриття представництв Німецької імперії на початку Першої світової війни.

Книзі, як і багатьом іншим роботам авторів, притаманні скрупульозність, критичність до джерел і праць попередників (інколи навіть занадто, про що ми скажемо нижче), грунтовність до висвітлення обраної теми. Праця наповнена великою кількістю ілюстративного матеріалу (від світлин імперського часу до власних авторських фотографій і репринтів документів).

Навіть побіжне ознайомлення зі змістом і компоновкою книги дозволяє зро- 
бити висновок, що пророблена величезна емпірична робота в архівах і бібліотеках України та зарубіжжя (і про це автори без зайвої скромності заявляють у передмові, розкриваючи процес появи книги від зародження ідеї до її видання). Звісно, що на цьому поприщі ще багато перспективної роботи: вивчення документів російських архівів: у Ростові-на-Дону та Архіву зовнішньої політики Російської імперії (м. Москва), здобутків німецької історіографії, яка залишилася майже незалученою тощо, але вагомий крок зроблено і ми тримаємо у руках досить добротний науковий продукт з історії німецьких консульств (а точніше - консулів) в українському Приазов'ї.

Монографія побудована на історико-біографічному підході до висвітлення суспільних процесів, де основна увага приділяється ролі особистості консула у житті досліджуваного регіону. Логічна структура роботи проста та зрозуміла і складається з передмови, узагальнюючого розділу про зв'язки Бердянська та Маріуполя з німецькими землями і німецькими колоністами до облаштування консульств, історичних нарисів про консулів та їх родини, додатків.

Останні складають у книзі більше половини обсягу книги та представлені: списками іноземних консулів у Бердянську та Маріуполі в XIX - на початку XX ст., витягами з рапортів британських консулів про німецьку торгівлю в азовських портах, фотокопіями документів з німецького Політичного федерального архіву МЗС і Федерального архіву Німеччини (Das Bundesarchiv). Віддаючи належне ілюстративності та змістовності додатків, висловимо побажання у подальшому подавати документи (маємо на увазі звіти британських консулів) не в англомовному варіанті, а в українському перекладі, що б зробило доступнішим матеріал широкому загалу. Зазначене стосується і до німецьких фотокопій, які стали б набагато ціннішими для наукового обігу, якби були перекладені та відповідним чином археографічно опрацьовані.

Усього праця містить сім нарисів про німецьких консулів: у Бердянську - Корнеліуса Янцена, Йоганна Геммерле, Карла Оссенкопа й Александра Зуккау та Маріуполі - Матіаса Ковачевича, Івана Деспота й Евальда Бремера.

Як свідчать відтворені біографії консулів та їх родин, автори залучили максимум доступного фактологічного й ілюстративного матеріалу, що інколи навіть призводить до певних перегинів. Так, наприклад, більшість ( $2 / 3$ тексту) біографічного нарису про віце-консула Александра Зуккау займає матеріал про Джона Грієвза, його родину та сімейну компанію «Джон Грієвз і К», який нам добре відомий із попередньої праці авторів «Британський консул і промисловець Джон Грієвз» (Бердянськ, 2017), але, при цьому, їх пов'язували лише професійні підприємницькі інтереси. Нам здається, що така велика увага авторів до Дж. Грієвза є зайвою і достатньо було б відіслати читача до вже згаданої вище книги.

Як вже зазначалося нами вище, авторів відрізняє ретельність у роботі з джерелами й, інколи, занадто прискіплива критика до своїх попередників. Наприклад, згадуючи (С. 171) дисертацію Л. Вовчук, автори закидають їй, що вона згадала лише одного німецького консула у Бердянську та ще й послалася на статтю І. Лимана та В. Константінової «Бердянские консулы» (знаходилася на сайті http://ri-urbanhistory.org.ua у лютому 2013 р.). На сьогодні даної статті вже на вказаному сайті немає. I воно зрозуміло, оскільки ретельна робота авторів над темою привела їх до того, що у статті присутнє багато помилок, які по- 
родженні обмеженістю джерельної бази ${ }^{1}$. Але ж дійсно, у даній статті згадується лише один німецький консул - Йоганн Геммерле (за наявними джерелами на 2013 р.), а вже у публікації шанованих дослідників 2014 р., що розміщена на сайті проекту «Портові міста Чорного моря» («Black Sea Project Port Cities»), вказано вже 2 (!) консули (див.: https://cities.blacksea.gr/ru/berdyansk/1-8-2/) і про час заснування та діяльності консульства вказано лише те, що воно «існувало вже у 1872 р.» (https://cities.blacksea.gr/ru/berdyansk/1-8-1/). Натомість власних праць автори монографії критиці не піддають. На наше глибоке переконання, головна задача вчених, що працюють паралельно у близькій темі, не критикувати огульно своїх колег, а творчо співпрацювати, доповнюючи та виправляючи помилки один одного.

Разом з тим, висловлюючи певні побажання у подальшій роботі над серією «Історія іноземних консульств на Півдні України», хотілося б побажати авторам більше уваги приділяти безпосередньо консульській діяльності дипломатичних представників як Німеччини, так й інших країн. Адже у результаті змістовна частина книги пояснює назву здебільшого тим, що усі біографії об'єднанні «другорядним» обов'язком їх життя - виконанням консульських зобов'язань, що дуже часто в азово-чорноморському регіоні виступало або ж як почесний обов'язок, або ж як засіб для забезпечення успішного ведення власного бізнесу (винятком є Великобританія, Японія та декілька інших держав, які були представлені здебільшого професійними дипломатами).

Також було б корисним у подібних працях у майбутньому робити іменний i географічний покажчики, що б полегшило науковцям та усім зацікавленим, працю з такою корисною та змістовною книгою.

У підсумку хотілося б побажати авторам творчої наснаги та натхнення у створенні нових грунтовних праць як з історії іноземних консульств, так і в інших тематичних напрямках, які будуть лише збагачувати та популяризувати українську історичну науку на світовій арені.

\footnotetext{
1 Саме цим пояснюється присутність багатьох неточностей у дисертації Л. Вовчук, яка була піонером у даній темі, адже коли у 2007 р. вийшла наша перша спільна праця присвячена діяльності іноземних консульств у Миколаєві (див.: Вовчук Л., Тригуб О. Основні напрямки діяльності іноземних консульств на Півдні України у другій половині XIX - початку XX ст. (на прикладі Миколаєва). Емінак: науковий щоквартальник. 2007. № 2 (жовтень-грудень). С. 90-97), то вона була однією з перших подібних робіт у даному дослідницькому напрямку в українській історіографії. У своїй дисертації Д. Вовчук намагалася охопити широке коло питань історії діяльності усіх (!) іноземних консульств у містах азовсько-чорноморського узбережжя Російської імперії для створення першої узагальнюючої праці і, звісно, не могла фізично охопити усе коло джерел.
} 